\title{
Biology of Bemisia tuberculata Bondar (Aleyrodidae) and parasitism by Encarsia porteri (Mercet, 1928) (Hymenoptera, Aphelinidae) on cassava plants
}

\author{
Andrade Filho, NN. ${ }^{a}$, Roel, AR. ${ }^{a *}$, Penteado-Dias, AM. ${ }^{b}$ and Costa, $R B^{c}$

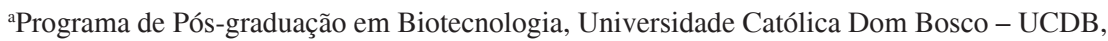 \\ Av. Tamandaré, 6000, CEP 79117-900, Campo Grande, MS, Brazil

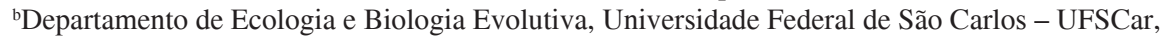 \\ CP 676, CEP 13565-905, São Carlos, SP, Brazil \\ 'Programa de Ciências Florestais e Ambientais, Universidade Federal do Mato Grosso - UFMT, \\ Av. Fernando Corrêa da Costa, s/n, CEP 78060-900, Cuiabá, MT, Brazil \\ *e-mail: arroel@ucdb.br
}

Received March 24, 2011 - Accepted January 26, 2012 - Distributed November 30, 2012 (With 4 figures)

\begin{abstract}
The whitefly Bemisia tuberculata has caused serious damage to cassava producing areas in the state of Mato Grosso do Sul. However, little is known about the biological characteristics of this species. The objective of this study was therefore, to monitor the development of this species bred on cassava plants under controlled greenhouse conditions, and to determine its most vulnerable stages and its reproductive capacity, as well as measuring the length and width each stage of development. To obtain these data, adult individuals were kept in voile traps on cassava leaves of five different plants, totalling ten leaves. After 24 hours the leaves were removed from the traps thus making each egg-laden leaf an experimental unit. The lowest mortality rate was record in the last nymphal stage ("pupae) compared with the other development stages. The highest mortality occurred in the nymphs at the $2^{\text {nd }}$ and $3^{\text {rd }}$ instars. Each female laid an average of 6.3 eggs in 24 hours. Thirteen days after egg laying, every one of the nymphs was fixed on the leaves of cassava plants. From the egg laying stage up until the adult stage, the process took 26 days. The proportion of females was $73.5 \%$. The average size of the $B$. tuberculata egg was $163.22 \mu \mathrm{m}$ in length and $72.39 \mu \mathrm{m}$ in width and the "pupae" is $915.82 \mu \mathrm{m}$ in length and $628.71 \mu \mathrm{m}$ in width. The measurements of males were $797.16 \mu \mathrm{m}$ in length and $200.81 \mu \mathrm{m}$ in width and the length females $916.12 \mu \mathrm{m}$ in length and $338.99 \mu \mathrm{m}$ in width. The parasitoid Encarsia porteri (Mercet, 1928) (Hymenoptera, Aphelinidae) was found in the insect stock culture.
\end{abstract}

Keywords: cassava pest, life table, Manihot esculenta.

\section{Biologia de Bemisia tuberculata (Hemiptera: Aleyrodidae) em mandioca}

\begin{abstract}
Resumo
A mosca-branca Bemisia tuberculata tem causado sérios danos a áreas produtoras de mandioca do Estado do Mato Grosso do Sul. No entanto, pouco se sabe sobre as características biológicas dessa espécie. O objetivo deste trabalho foi, portanto, acompanhar o desenvolvimento dessa espécie criada em plantas de mandioca em condições de casa de vegetação, além de determinar as suas fases mais vulneráveis e a sua capacidade reprodutiva, e medir o comprimento e a largura das fases de desenvolvimento. Para obter esses dados, os indivíduos adultos foram mantidos em armadilhas voil de folhas de mandioca, de cinco plantas diferentes (duas folhas por planta), totalizando dez folhas. Após 24 horas, as folhas foram retiradas das armadilhas, tornando-se cada folha carregada de ovos uma unidade experimental. Na última fase de ninfa (pupa), a menor taxa de mortalidade foi observada, em comparação com os outros estágios de desenvolvimento. A maior mortalidade ocorreu em ninfas, fixadas em segundo e terceiro ínstares. Cada fêmea depositou uma média de 6,3 ovos em 24 horas. Após 13 dias de postura dos ovos, todas as ninfas estavam fixas nas folhas das plantas de mandioca. A partir da postura dos ovos até a fase de aparecimento dos adultos, foram necessários 26 dias. Houve uma proporção de 73,5\% de fêmeas. Os ovos de B. tuberculata medem 163,22 $\mu$ m de comprimento e $72,39 \mu \mathrm{m}$ de largura. A pupa mede $915,82 \mu \mathrm{m}$ de comprimento e $628,71 \mu \mathrm{m}$ de largura. O macho mede 797,16 $\mu \mathrm{m}$ de comprimento e 200,81 $\mu \mathrm{m}$ de largura, e a fêmea mede $916,12 \mu \mathrm{m}$ de comprimento e 338,99 $\mu \mathrm{m}$ de largura. O parasitoide Encarsia porteri (Mercet, 1928) (Hymenoptera, Aphelinidae) foi encontrado na criação estoque.
\end{abstract}

Palavras-chave: pragas da mandioca, tabela de vida, Manihot esculenta. 


\section{Introduction}

Cassava (Manihot esculenta Crantz) is a staple food for millions of people around the world. However, plant health problems during cultivation have been found including the appearance of the whiteflies (Aleyrodidade) which impairs crop development and reduces yield.

Extraordinarily high levels of whitefly are one of the major and limiting problems affecting the cassava crop in the towns of Deodápolis and Ivinhema, the most important cassava producing regions of the state of Mato Grosso do Sul, Brazil. Whiteflies suck the sap from plants directly damaging apical leaves thereby causing curling, chlorosis, yellowing and wilting as well as necrosis and leaf fall. The sucked sap is subsequently excreted in the form of honeydew (Oliveira and Lima, 2006) which acts as a substrate for the development of the Capnodium sp. mould fungus. In turn the fungus causes a symptom known as "sooty mould" which forms a mechanical barrier to photosynthesis (Moreira and Farias, 2006). In terms of indirect damage, Aleyrodidae have been cited as phytopathogenic virus vectors both in nymphs and adults. According to Smith (2002), cassava crops attacked by this pest have roots that are more fibrous and contain higher water concentrations thus causing reduced productivity depending on the species variety and intensity of the attack.

The whiteflies life cycle varies according to climate and the host plant they are found on (Oliveira and Lima, 2006). In the first instar, the nymphs are known as crawlers since they possess three pairs of legs enabling them to move to a chosen site. The other subsequent instars of the immature phase are immobile and remain so until they become adults (Hoddle and Soliman, 2001). In the fourth instar, feeding is halted and the morphological changes occur. This stage is referred to as "pupae" or "pseudo-pupae" (Gallo et al., 2002).

According to Oliveira and Lima (2006), B. tuberculata Bondar is the whitefly that affects the largest number of cassava crops in the state of Mato Grosso do Sul due to extensive farming methods and the lack of natural enemies. Some studies have been conducted under field conditions but these do not specify which whitefly species were being studied. However, little is known about the biology of B. tuberculata under controlled conditions thereby making it difficult to develop specific control measures. This research aims to establish biological parameters and morphometric measures, length and width, of eggs, "pupae" and adults of this species under controlled conditions.

\section{Material and Methods}

The experiment was conducted in a greenhouse located in Campo Grande, in the state of Mato Grosso do Sul, from January to February 2008. Temperature was maintained at $26 \pm 4{ }^{\circ} \mathrm{C}$, by a Pad- Fan climate and humidity control system using an automatic system. The plants used to set up a stock and to conduct the experiments on were threemonth old cv Paraná cassavas grown in five-litre black plastic bags. Fertilizing was carried out according to crop recommendations based on soil analysis (Otsubo et al., 2002).

White voile traps with a velcro clasp and containing a cassava leaf were used. Twenty adult whiteflies, males and females, in each trap were confined for 24 hours and then removed to form the stock. After removal from the traps, egg counts were made. Each treatment was repeated five times using five plants with an average of two leaves (sub-samples) per plant. Data collection of the development of $B$. tuberculata was conducted on a daily basis using a watchmaker-style eye loupe $(30 \times)$.

Life expectancy was calculated per development phase using Southwood (1978) life-tables whereby $x=$ age interval in units of time (days ...); Lx = survivorship at each stage; Dx = number of deaths during each age interval; $\mathrm{Ex}=$ number of survivors between one stage and the next (age structure); $\mathrm{Tx}=$ the total number of insects at age $\mathrm{x}$, beyond age $\mathrm{x}$; ex = life expectancy (le), $1000 \mathrm{qx}=\mathrm{Dx} /$ Lx (mortality rate).

To obtain the sex ratio, one thousand flies were taken at random from the experimental colony by means of a manual aspirator. The separation of the sexes was carried out with the aid of a stereo-microscope ( 8 to $50 \times$ magnification) (NIKON) following Villas Bôas et al. (2002). The sex ratio (SR), the proportion of males and females per generation, was obtained by dividing the number of females by the number of females + the number of males. Eggs, "pupae" and adults, male and female, were photographed using a Leica DC150 digital camera (coupled to a Wild M8 stereomicroscope). To gather morphometric data, length and width measurements, were taken from 50 eggs, 50 "pupae", 50 male adults and 50 female adults of B. tuberculata with the aid of a microscope coupled to a computer using a KS400 program.

The leaf samples with the whitefly nymphs collected for breeding were sent to M.Sc. Aurino Lima Florêncio de Lima, at the Federal Rural University of Rio de Janeiro (UFRRJ) for identification of the whitefly species. The parasitoids collected from parasitized nymphs in the greenhouse were identified by one of the authors (AMPD).

\section{Results}

Higher mortality was observed in the initial phase, that is, between egg-laying and the nymphs fixing themselves on leaves was $57.5 \%$, whilst only $12.7 \%$ of mortality was observed in the final nymph instar ("pseudo-pupal") (Table 1).

Under the conditions established for this study, each female was able to lay an average of 6.3 eggs in the 24-hour period in which they were kept confined in the traps. From the egg laying stage until adult emergence, this process took 26 days. The period from egg-laying to nymph fixing, was 13 days on the average whilst from the young nonmobile phase $\left(2^{\text {nd }}, 3^{\text {rd }}\right.$ and $4^{\text {th }}$ instars $)$ to the adult emergence approximately 13.58 days, were necessary (Table 2 ). The mean of the sex ratio of the $B$. tuberculata whitefly in this study was 0.735 , i.e. $73.5 \%$ for female individuals. 
Table 1. A Southwood (1978) model life-table of Bemisia tuberculata on cassava plants in a greenhouse, Temp.: $26 \pm 4{ }^{\circ} \mathrm{C}$. Campo Grande, MS, 2008.

\begin{tabular}{lcccccc}
\hline \multicolumn{1}{c}{$\mathbf{X}$} & $\mathbf{L x}$ & $\mathbf{D x}$ & $\mathbf{E x}$ & $\mathbf{T x}$ & $\mathbf{e x}$ & $\mathbf{1 0 0 0} \mathbf{q x}$ \\
\hline Egg-laying and the nymphs fixing & 925 & 532.0 & 659 & 982.5 & 1.062 & 575 \\
Nymph (2 (nd $^{\text {rd }}$ instar) & 393 & 338.0 & 224 & 323.5 & 0.823 & 860 \\
Nymph 4 $4^{\text {th }}$ instar ("pupae") & 55 & 7.0 & 51.5 & 99.5 & 1.809 & 127 \\
Adult & 48 & 7.0 & 48 & 48 & 1.000 & 1000 \\
\hline
\end{tabular}

$\mathrm{x}=$ age interval in time units (days...); Lx = number of survivors at the beginning of age $\mathrm{x}$; Dx = number of deaths during the age interval; Ex = number of survivors between one stage and the next (age structure); Tx = total number of insects at age $\mathrm{x}$, beyond age $\mathrm{x}$; ex $=$ life expectancy $(\mathrm{ex})=\mathrm{Tx} / \mathrm{Lx} ; 1000 \mathrm{qx}=1000 \mathrm{Dx} / \mathrm{Lx}$ (mortality rate)

Regarding morphometric data (Table 3), the average size of the $B$. tuberculata egg was $163.22 \mu \mathrm{m}$ in length and $72.39 \mu \mathrm{m}$ in width (Figure 1a) and $915.82 \mu \mathrm{m}$ in length and $628.71 \mu \mathrm{m}$ in width for the "pupae" (Figure 1c). The females were larger than males measuring $16.12 \mu \mathrm{m}$ in length by $338.99 \mu \mathrm{m}$ in width (Figure 1d) while the males were $797.16 \mu \mathrm{m}$ in length by $200.81 \mu \mathrm{m}$ in width (Table 3).

In the different development stages, the causes of death were not noted. But it was discovered that the Encarsia porteri (Mercet) (Hymenoptera, Aphelinidae, Chalcidoidea) parasitoids caused the death of insect stock culture (Figure 1b).

\section{Discussion}

The results obtained in this work, regarding highest mortality rate in young nymphs and the lowest in the "pupae", corroborate the findings of Albergaria et al. (2003) found similar results for B. tabaci with greater mortality in the $2^{\text {nd }}$ and $3^{\text {rd }}$ instars but the causes of death were not identified.

Analysing the mortality data obtained from the different stages it was found that of the total of 925 eggs (a total of ten oviposition), 393 became nymphs fixed on the leaves, i.e. a mortality rate of $57.51 \%$. Similar data were obtained by Souza and Vendramim (2004) who reported that the B. tabaci species has an egg viability of between $50 \%$ and 95\% depending on temperature and host.

Of the 393 nymphs fixed on leaves, only 55 reached the final nymph stage ("pupae") resulting in a mortality rate of $86.01 \%$. High mortality rates in this stage were also found by other authors studying other species of whitefly showing this to be the most susceptible stage to mortality factors. On the other hand, Hoddle and Soliman (2001), studying the Tetraleurodes perseae whitefly, found that after hatching, the first instar or crawler is most susceptible to mortality factors. In studies of the $B$. argentifolii whitefly, Albergaria et al. (2003) highlighted the fact that the simultaneous contribution of mortality factors in the egg, 1st instar and last nymph instar stages was small when compared with the mortality rate found in the $2^{\text {nd }}$ and $3^{\text {rd }}$ instars, i.e. the mortality rate tends to be higher in the intermediate development stages.

Of the 55 individuals in the last nymph stage ("pupae"), 48 reached adulthood meaning there was a mortality rate of
Table 2. Duration of the stages (mean \pm standard error of the mean) in distinct development periods of Bemisia tubercula, on cassava, in a greenhouse, Temp.: $26 \pm 4{ }^{\circ} \mathrm{C}$. Campo Grande, MS. 2008.

\begin{tabular}{lc}
\hline \multicolumn{1}{c}{ Period } & $\begin{array}{c}\text { Duration } \\
\text { (days } \pm \text { sem) }\end{array}$ \\
\hline $\begin{array}{l}\text { Incubation period up to fixed } \\
\text { nymph stage }\end{array}$ & $13.00 \pm 1.00$ \\
Fixed nymph period and "pupae" & $13.58 \pm 0.86$ \\
Total & $26.08 \pm 0.86$ \\
\hline
\end{tabular}

sem $=$ Standard error of the mean.

$12.73 \%$. This stage proved to be the one with the highest survivorship in $B$. tabaci populations.

The period from the young non-mobile phase of B. tuberculata in this study ( $2^{\text {nd }}, 3^{\text {rd }}$ and $4^{\text {th }}$ instars $)$ to the adult emergence phase lasted an average of 13.58 days. In a study of Bemisia spp in Mato Grosso do Sul, Calado-Filho et al. (2007) recorded a nymph stage of 18.48 days at an average temperature of $20.99^{\circ} \mathrm{C}$, which is considered to be the main influencing factor on the development of whiteflies. Therefore, it can be assumed that the difference in the duration of the stages can also be explained by the differences in temperatures adopted in different studies and/or nutritional factors determined by the different varieties used as hosts. Considering the difference in temperature and variety of cassava, Rheinheimer et al. (2009) reported that B. tuberculata created cassava plant varieties "Cascuda" and "Fécula Branca", at a temperature of $25+3{ }^{\circ} \mathrm{C}$ the cycle from egg to adult between 31.7 and 32.7 days for varieties "Cascuda" and "Fécula Branca", respectively.

The sex ratio of the $B$. tuberculata in this study meets expectations regarding the reproduction characteristics of these insects and is similar to results from other studies on Bemisia spp, in which ratios were found of 1 male per 2.7 females (Salas and Mendonza, 1995; Lacerda and Carvalho (2008). Studies on B. tabaci by Souza and Vendramim (2004) found a sex ratio of $70 \%$ females regardless of temperature. However, the sex ratio of Bemisia spp. can change according to the species and/or host plant. In relation to the biotic potential of $B$. argentifolii, Villas Bôas et al. (2002) reported differences depending on the plants they developed on and concluded that although the sex ratio 
is always higher in females, on cassava plants there was a sex ratio of 0.5 females: 1.0 males on cassava plants.

The B. tuberculata eggs are smaller than those of B. tabaci, although both are the same shape and colour. According to Souza and Vendramim (2004) the B. tabaci eggs are piriform, with a smooth texture and measure between 0.18 to $0.21 \mathrm{~mm}$ in length and 0.06 to $0.09 \mathrm{~mm}$ in width and they are fixed onto the abaxial side of the leaf. Initially the eggs were white in colour becoming yellow and darkening as embryonic development progressed (Oliveira and Lima, 2006).

In relation to sexual dimorphism, besides size differences it was found that the females have a rounded lower abdomen while the males have a lower abdomen in the shape of pincers (Figure 1d), similar to the descriptions made by Villas Bôas et al. (2002) when describing B. tabaci.
About the occurrence of the E. porteri in the colony of B. tuberculata Polaszek (1992) reported two genera, Encarsia and Eretmocerus, as having the greatest association with B. tabaci ' $\mathrm{B}$ ' breed, both belonging to the Aphelinidae family. The Chalcioidea together with Ichneumonoidea predominated in the native forest ecosystem. The Chalcididae, and other Chalcidoidea, are one of the biggest tropical groups of insects and are particularly diverse, according to Marchiori et al. (2007). In addition to this, Parra et al. (2002) confirm that many of the superfamily species have the potential to be used in biological control programmes.

Acknowledgements - To The Pantanal Research Center (CPP), the Ministry of Science and Technology (MCT) and the Foundation for the Support of Teaching, Science and Technology Development of the state of Mato Grosso do Sul (FUNDECT), for financial support. To Aurino Florêncio de Lima (Federal Rural University of Rio de Janeiro, UFRRJ)

Table 3. Morphometric data (mean \pm standard error of the mean, measured in $\mu \mathrm{m}$ ), of the eggs, "pupae" and adults of Bemisia tuberculata bred on cassava leaves in a greenhouse, Temp.: $26 \pm 4{ }^{\circ} \mathrm{C}$. Campo Grande, MS. 2008.

\begin{tabular}{lcccc}
\hline \multicolumn{1}{c}{ Variable } & Eggs & "Pupae" & Females & Males \\
\hline Length & $163.22 \pm 0.15$ & $915.83 \pm 1.17$ & $916.12 \pm 9.08$ & $797.17 \pm 7.33$ \\
Width & $72.389 \pm 0.12$ & $628.72 \pm 1.62$ & $338.99 \pm 0.92$ & $200.81 \pm 4.19$ \\
\hline
\end{tabular}
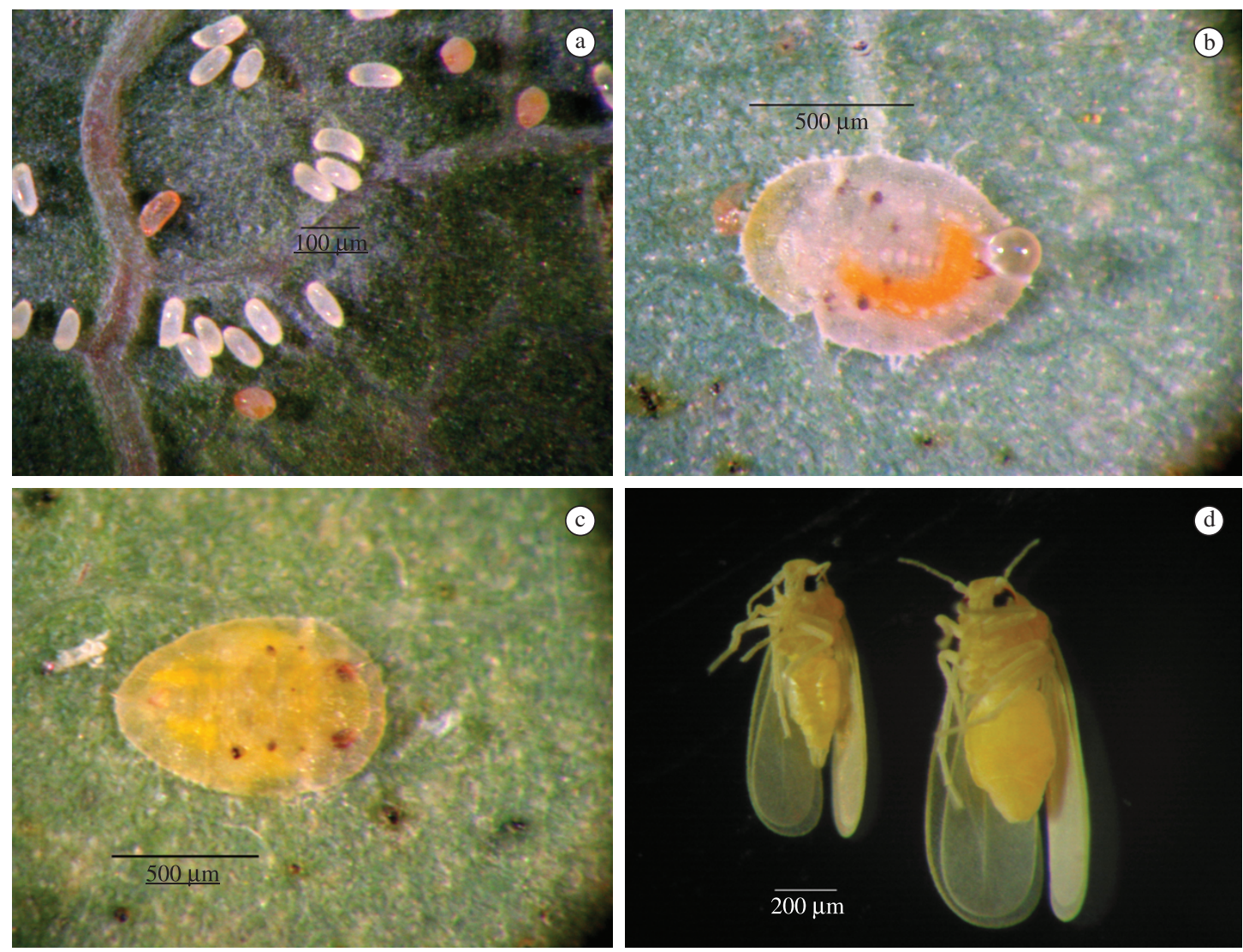

Figure 1. Bemisia tuberculata a) Eggs, b) Parasitized nymphs, c) "pupae” d) adults, male (left) and female (right) in cassava plants in greenhouse, Temp.: $26 \pm 4{ }^{\circ} \mathrm{C}$. Campo Grande, MS. 
for the identification of the whitefly species. To Dr. José Raul Valério (Embrapa - CNPGC) for providing the equipment required to obtain the morphometric data and photographs.

\section{References}

ALBERGARIA, NMMS., CIVIDADES, FJ. and DÓRIA, HOS., 2003. Ecological life table of Bemisia tabaci (Genn.) B-biotype (Hemiptera: Aleyrodidae). Neotropical Entomology, vol. 32, p. 559-563. http://dx.doi.org/10.1590/S1519-566X2003000400005

CALADO FILHO, GC., TOSCANO, LC., AGUIRRE, WM., MARUYAMA, WI. and SILVA, RFR., 2007. Biologia de Bemisia sp. em plantas de mandioca. In Anais do XII Congresso Brasileiro da Mandioca, 2007. Paranavaí. Mandioca: Bioenergia, Alimento e Renda.

GALLO, D., NAKANO, O., SILVEIRA NETO, S., CARVALHO, RPL., BAPTISTA, GC., BERTI FILHO, E., PARRA, JRP., ZUCCHI, RA., ALVES, SB., VENDRAMIM, JD., MarChini, LC., LOPES, JRS. and OMOTO, C., 2002. Entomologia Agrícola. Piracicaba: FEALQ, 920 p.

HODDLE, MS. and SOLIMAN, GN., 2001. Developmental and reproductive biology of the red-banded whitefly, Tetraleurodes perseae Nakahara (Homoptera: Aleyrodidae). Department of Entomology, University of California, Riverside. 7 p.

LACERDA, JT. and CARVALHO, RA., 2008. Descrição e manejo integrado da mosca-branca (Bemisia spp.) transmissora de geminivirus em culturas econômicas. Tecnologia e Ciência Agropecuária, vol. 2, p. 15-22.

MARCHIORI, CH.; LUSSARI, MA. and PENTEADO-DIAS, AM., 2007. Parasitoid Hymenoptera collected during the diurnal and nocturnal periods in Itumbiara, Goiás. Brazilian Journal of Biology, vol. 67, no. 3, p. 581-582.

MOREIRA, MAB., FARIAS, AR., ALVES, MCS. and CARVALHO, HWL., 2006. Alternativas para o controle da mosca-branca Aleurothrixus aepim na cultura da mandioca em Sergipe. Aracaju: Embrapa - Tabuleiros Costeiros. 6 p. (Comunicado Técnico, n. 56).
OLIVEIRA, MRV. and LIMA, LHC., 2006. Moscas brancas na cultura da mandioca no Brasil. Brasília: Embrapa - Cenargen. 74 p. (Documentos, n. 186).

OTSUBO, AA., MERCANTE, FM. and MARTINS, CS. (Eds.), 2002. Aspectos do cultivo da mandioca em Mato Grosso do Sul. Dourados: Embrapa Agropecuária Oeste; Campo Grande: Uniderp. 219 p.

PARRA, JRP., BOTELHO, PSM., CORRÊA-FERREIRA, BS. and BENTO, JMS., 2002. Controle biológico: terminologia. In -. Controle biológico no Brasil: parasitóides e predadores. Barueri: Editora Manole. p. 17-27.

POLASZEK, A., 1992. Encarsia parasitoids of Bemisia tabaci (Hymenoptera: Aphelinidae, Homoptera: Aleyrodidae): a preliminary guide to identification. Bulletin of Entomological Research, vol. 82, p. 375-392. http://dx.doi.org/10.1017/S0007485300041171

RHEINHEIMER, AR., BELLON, PP., HACHMANN, T., MIRANDA, AM., SCHERER, WA., PIETROWSKI, V., ALVES, LFA. and PINTO JUNIOR, AS., 2009. Biologia da mosca branca (Bemisia tuberculata Bondar) (Hemiptera: Aleyrodidae) em mandioca. In Anais do XIII Congresso Brasileiro da Mandioca, 2009. Brasil: SBM. p. 265-269.

SALAS, J. and MENDOZA, O., 1995. Biology of the sweetpotato whitefly (Homoptera: Aleyrodidae) on tomato. Florida Entomologist, vol. 78, p. 154-160. http://dx.doi.org/10.2307/3495680

SCHMITT, AT., 2002. Principais insetos e pragas da mandioca e seu controle. In CEREDA, MP. (Coord.). Agricultura: tuberosas amiláceas latino americanas. São Paulo: Fundação Cargill. p. 350369. (Culturas de Tuberosas Amiláceas Latinoamericanas, no. 2).

SOUTHWOOD, TRE., 1978. The construction description and analysis of age-specific life tables. London: Chapman Hall. p. 356-387.

SOUZA, AP. and VENDRAMIN, JD., 2004. Bioactivity of organic and aqueous extracts from meliaceous plants on Bemisia tabaci (Genn.) biotype b on tomato plants. Arquivos do Instituto Biológico, vol. 71, p. 493-497.

VILLAS BÔAS, GL., FRANÇA, FHA. and MACEDO, N., 2002. Biotic potential of Bemisia argentifolii to different host plants. Horticultura Brasileira, vol. 20, p. 71-79. 
